\title{
An Updated Evidence About the Role of Timing to Debridement on Infection Rate of Open Tibial Fractures: A Meta-Analysis
}

\author{
Ahmed Elnewishy ${ }^{1}$ \\ 1. Orthopaedic Surgery, Kasr Al-Ainy Medical School, Kafr El Sheikh, EGY
}

Corresponding author: Ahmed Elnewishy, ahmed.elnewishy93@gmail.com

\section{Abstract \\ Background and objectives}

Recent experimental and clinical evidence supporting early debridement for open fractures has been questioned. Therefore, this systematic review and meta-analysis aimed to summarize and evaluate the current evidence regarding the timing of surgical debridement of open tibial fractures.

\section{Methods}

A systematic review and meta-analysis were conducted on studies compared the infection rate following early versus late debridement of open tibial fractures. We performed an online, bibliographic, search through the period from January 2000 to June 2020 in five bibliographic databases: Cochrane Central Register of Controlled Trials (CENTRAL), Medline via PubMed, Web of Science, Scopus, and EBSCO host.

\section{Results}

Nine retrospective studies and six prospective studies were included in the present meta-analysis study. The pooled effect estimate showed no statistically significant difference between early and late debridement regarding the overall infection rate ( $\mathrm{RD} 0.02,95 \% \mathrm{CI}[0-0.04], \mathrm{p}=0.94$ ); there was no significant heterogeneity in the pooled estimate ( $(2=5 \%)$. The subgroup analysis showed that the non-significant difference was consistent regardless of the definition of early and late timing to debridement. Likewise, the pooled effect estimate showed no statistically significant difference between early and late debridement regarding the deep infection rate $(\mathrm{RD} 0.01,95 \% \mathrm{CI}[-0.01-0.03], \mathrm{p}=0.92)$; there was no significant heterogeneity in the pooled estimate ( $\mathrm{I} 2=0 \%$ ). The pooled effect estimate showed no statistically significant difference between early and late debridement regarding the nonunion rate as well. The funnel lots showed little evidence of asymmetry by visual inspection.

\section{Conclusion}

Received 08/30/2020 Review began 09/03/2020 Review ended 09/03/2020 Published 09/11/2020

๑) Copyright 2020 Elnewishy. This is an open access article distributed under the terms of the Creative Commons Attribution License CC-BY 4.0., which permits unrestricted use, distribution, and reproduction in any medium, provided the original author and source are credited.
In conclusion, the current evidence demonstrates no impact of timing to surgical debridement on the infection rate following open tibial fractures in the adult population. Our results demonstrated that the risks of infection, deep infection, and nonunion were similar between patients who underwent delayed versus early debridement.

Categories: Emergency Medicine, Orthopedics, Trauma
Keywords: early debridement, open fractures, tibia, meta-analysis.

\section{Introduction}

Tibia fractures are the most common long bone fractures with an infection rate of 20 times higher than other open long bone fractures [1]. According to the epidemiologic studies, the incidence rate of open long bone fractures is 11.5 per 100,000 persons annually [2]. It was estimated that the prevalence of infection following internal fixation of fractures could reach up to $30 \%$ in open fractures. Several tissue damage and wound contamination can lead to bone and soft tissue necrosis and infection due to open fractures. In severe cases, dysfunction of the limb and several organ failures can occur [3].

The number of open fractures and similar high-energy injuries has increased despite the advances in antibiotics, fracture stabilization, and wound management, which dramatically decreased the mortality from open fractures. Therefore, many investigators were proposed urgent operative debridement of open tibial fractures along with early administration of antibiotics [4-6]. In order to reduce the risk of infection and nonunion, it has been recommended that open tibial fractures should be debrided within 6 hours from injury, which is known as the 6-hour rule [7]. The 6-hour rule comes from a study of Friedrich that was conducted on guinea-pigs and showed that all animals remained healthy when debridement of open wounds was performed within 6 hours [8]. However, if the time after injury is $>24 \mathrm{~h}$, debridement is not 
recommended due to bacterial multiplication. In medical practice, several external variables will delay the timing of debridement in emergency surgery, including the delay in delivery, the patient's unstable condition, and other combined injuries being treated urgently [9]. Hence, debriding some patients within 6 hours after the injury is difficult. Despite these recommendations, some retrospective studies suggest that time to debridement is not a major determinant of the outcome [10,11]. Moreover, the experimental and clinical evidence supporting this recommendation has been questioned [12-15]. Therefore, this systematic review and meta-analysis aimed to summarize and evaluate the current evidence regarding the timing of surgical debridement of open tibial fractures.

\section{Materials And Methods}

We followed the recommended standards provided by the second edition of the Cochrane Handbook for Systematic Reviews of Intervention during the conduction of the present systematic review [16]. The writing of the present manuscript was done in strict adherent to the Preferred Reporting Items for Systematic Reviews and Meta-Analyses (PRISMA) statement [17].

\section{Eligibility criteria}

Studies in English language were deemed eligible for the present systematic review if they met all of the following criteria: 1 ) adult patients ( $\geqslant 18$ years old) with open tibial fractures; 2 ) studies which compared the infection rate following early versus late debridement of open tibial fractures; and 3) prospective or retrospective studies were included. We excluded studies with duplicate dataset, narrative or systematic reviews, studies with no data regarding the infection rate, animal models, studies in which open tibial fractures represent less than $50 \%$ of the total number of included fractures, dissertations, and conference abstracts.

\section{Literature search strategy and screening}

We performed an online, bibliographic, search through the period from January 2000 to June 2020 in five bibliographic databases: Cochrane Central Register of Controlled Trials (CENTRAL), Medline via PubMed, Web of Science, Scopus, and EBSCO host. Various combinations of the following queries were utilized: Tibial fractures, open fractures, debridement, timing to debridement, infection rate. In order to remove duplicates from databases search, we downloaded the retrieved citations and imported them to EndNote X7 for duplicates removal. Then, the titles and abstracts of the remaining records were screened for eligibility. A second-round of screening was conducted on full-texts of potentially eligible abstracts for final inclusion in the present systematic review.

\section{Data extraction}

We developed a standardized data extraction form using Excel software for data retrieval and processing. The following data were extracted from each eligible study: first author name, year of publication, study design, number of participants, number of fractures, timing to debridement, main findings, age, gender, Gustilo grading, overall infection rate, deep infection rate, and non-union rate. The quality assessment of the included studies was done using Newcastle-Ottawa Scale (NOS) [18].

\section{Data analysis}

All data were analyzed using STATA version 16.0 (StataCorp LLC, College Station, TX). The pooled estimates of risk difference (RD) were calculated using random effect models with inverse variance weighting. The primary data for overall infection, deep infection and non-union (event and non-event) from each included article were used to estimate the risk difference for each study. Heterogeneity among included studies was assessed based on the visual examination and Cochrane $Q$ and the I2 statistics. Subgroup analysis was conducted to assess the risk of timing the primary outcomes. All findings were presented as RD with $95 \%$ confidence interval $(95 \% \mathrm{CI})$. P value less than 0.05 was considered significant.

\section{Results}

A total of 1353 records were retrieved from an online search. Of them, 1089 records were screened after duplicates removal. After the initial screening, 57 full texts were retained for a full evaluation. Out of them, 43 studies were excluded as they were narrative or systematic review $(n=26)$, irrelevant $(n=12)$, and conferences $(n=5$ ). Finally, a total of 15 studies (prospective studies $=6$; retrospective studies $=9$ ) were included in the present systematic review (See PRISMA flow diagram; Figure 1). 


\section{Cureus}

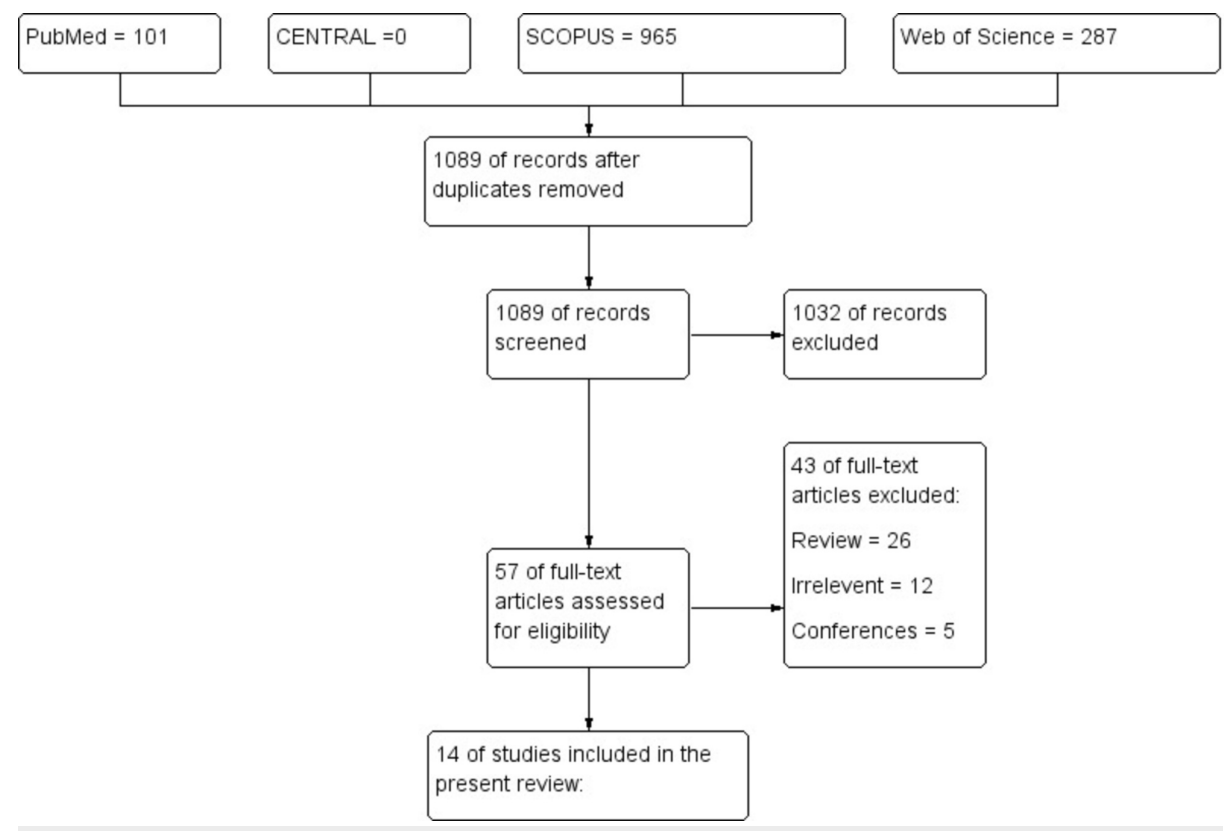

FIGURE 1: PRISMA flow diagram

Nine retrospective studies $[4,6,11,12,19-23]$ and six prospective studies $[3,5,10,15,24,25]$ were included in the present meta-analysis study. The number of fractures ranged from 41 to 383 fractures. The majority of fractures within the included studies were middle-third fractures. Nine studies compared early debridement within six hours from fracture to late debridement beyond those six hours, two studies compared early debridement within eight hours to late debridement beyond the eight hours, and one study compared < five hours to $\geqslant$ five hours and $<12$ hours to $\geqslant 12$ hours, each. In Li et al. and Srour et al. studies, multiple timings to debridement were compared (Table 1). The clinical characteristics of the included studies are shown in Table 2. 


\section{Cureus}

\begin{tabular}{|c|c|c|c|c|c|c|c|c|c|c|c|}
\hline \multirow{2}{*}{ Author } & \multirow{2}{*}{ Year } & \multirow{2}{*}{ Study design } & \multicolumn{3}{|c|}{ Type of fracture } & \multirow{2}{*}{$\begin{array}{l}\text { No. of } \\
\text { patients }\end{array}$} & \multirow{2}{*}{$\begin{array}{l}\text { No. of } \\
\text { fractures }\end{array}$} & \multirow{2}{*}{$\begin{array}{l}\text { Early } \\
\text { debridement }\end{array}$} & \multirow{2}{*}{ Late debridement } & \multirow{2}{*}{ Main findings } & \multirow{2}{*}{$\begin{array}{l}\text { Level of } \\
\text { evidence }\end{array}$} \\
\hline & & & Middle & $\begin{array}{l}\text { Proximal } \\
\text { third }\end{array}$ & Distal & & & & & & \\
\hline $\begin{array}{l}\text { Charalambous } \\
\text { et al. }\end{array}$ & 2005 & Retrospective & NA & $\mathrm{NA}$ & NA & 383 & 383 & $\leq 6$ Hours & $>6$ Hours & $\begin{array}{l}\text { No relation between debridement timing and } \\
\text { infection rate }\end{array}$ & IIII \\
\hline Khatod et al. & 2003 & Retrospective & 47 & 27 & 40 & 103 & 101 & $\leq 6$ Hours & $>6$ Hours & $\begin{array}{l}\text { No relation between debridement timing and } \\
\text { infection rate }\end{array}$ & III \\
\hline Spencer et al. & 2004 & Retrospective & 41 & 0 & 0 & . & 41 & $\leq 6$ Hours & $>6$ Hours & $\begin{array}{l}\text { No relation between debridement timing and } \\
\text { infection rate }\end{array}$ & $\|$ \\
\hline $\begin{array}{l}\text { Sungaran et } \\
\text { al. }\end{array}$ & 2007 & Retrospective & 161 & 0 & 0 & 161 & 161 & $\leq 6$ Hours & $>6$ Hours & $\begin{array}{l}\text { No relation between debridement timing and } \\
\text { infection rate }\end{array}$ & III \\
\hline Kamat & 2011 & Retrospective & 103 & 0 & 0 & & 103 & $\leq 6$ Hours & $>6$ Hours & $\begin{array}{l}\text { No relation between debridement timing and } \\
\text { infection rate }\end{array}$ & IIII \\
\hline $\begin{array}{l}\text { Enninghorst et } \\
\text { al. }\end{array}$ & 2011 & Prospective & 89 & 0 & 0 & 89 & 89 & $\leq 6$ Hours & $>6$ Hours & $\begin{array}{l}\text { Time to debridement is a predictor of poor } \\
\text { outcome }\end{array}$ & II \\
\hline Singh et al. & 2012 & Prospective & 25 & 8 & 34 & 67 & 67 & $\leq 6$ Hours & $>6$ Hours & $\begin{array}{l}\text { No relation between debridement timing and } \\
\text { infection rate }\end{array}$ & $\|$ \\
\hline $\begin{array}{l}\text { Reuss } \\
\text { and Cole }\end{array}$ & 2007 & Retrospective & 61 & 5 & 15 & 77 & 81 & $<8$ Hours & $>8$ Hours & $\begin{array}{l}\text { No relation between debridement timing and } \\
\text { infection rate }\end{array}$ & IIII \\
\hline Harley et al. & 2002 & Retrospective & NA & NA & NA & NA & 89 & $\leq 8$ Hours & $>8$ Hours & $\begin{array}{l}\text { No relation between debridement timing and } \\
\text { infection rate }\end{array}$ & IIII \\
\hline $\begin{array}{l}\text { Fernandes et } \\
\text { al. }\end{array}$ & 2015 & Prospective & NA & NA & NA & NA & 76 & 6 Hours & 6 Hours & $\begin{array}{l}\text { A significant increase in the rate of infection } \\
\text { was observed in those operated } 6 \text { hours after } \\
\text { trauma. }\end{array}$ & II \\
\hline $\begin{array}{l}\text { Hendrickson } \\
\text { et al. }\end{array}$ & 2018 & Retrospective & NA & NA & NA & 112 & 116 & $<12$ Hours & $>12$ Hours & $\begin{array}{l}\text { No relation between debridement timing and } \\
\text { infection rate }\end{array}$ & IIII \\
\hline Li et al. & 2020 & Retrospective & 74 & 48 & 93 & 215 & 215 & 6 Hours & $\begin{array}{l}6 \mathrm{~h}<\text { LFITFD } \leqq 12 \mathrm{~h} \\
\text { or } 12 \mathrm{~h}<\text { LFITFD } \\
24 \mathrm{~h}\end{array}$ & $\begin{array}{l}\text { No relation between debridement timing and } \\
\text { infection rate }\end{array}$ & III \\
\hline Pollak et al. & 2010 & Prospective & NA & NA & NA & 307 & 307 & $<5$ Hours & $>5$ Hours & $\begin{array}{l}\text { No relation between debridement timing and } \\
\text { infection rate }\end{array}$ & $\|$ \\
\hline Srour et al. & 2015 & Prospective & NA & NA & NA & 64 & 64 & 6 Hours & $\begin{array}{l}7 \text { to } 12 \text { hours; } 13 \text { to } \\
18 \text { Hours; or } 19 \text { to } 24 \\
\text { Hours }\end{array}$ & $\begin{array}{l}\text { No relation between debridement timing and } \\
\text { infection rate }\end{array}$ & II \\
\hline Al-Arabi et al. & 2007 & Prospective & NA & NA & NA & 237 & 248 & 6 Hours & $>6$ Hour: & $\begin{array}{l}\text { No relation between debridement timing and } \\
\text { infection rate }\end{array}$ & $\|$ \\
\hline
\end{tabular}

\section{TABLE 1: Summary of the included studies}

LFITFD: Length from injury to first debridement

\begin{tabular}{|c|c|c|c|c|c|c|c|c|c|}
\hline \multirow{2}{*}{ Author } & \multirow{2}{*}{ Group } & \multirow{2}{*}{ Mean age } & \multirow{2}{*}{ Males } & \multirow{2}{*}{ No. of fractures } & \multicolumn{5}{|c|}{ Gustilo grading } \\
\hline & & & & & 1 & 2 & $3 \mathrm{~A}$ & 3B & $3 C$ \\
\hline \multirow{2}{*}{ Charalambous et } & Early & 31 (Range 4-87) & 32 & 184 & 14 & 19 & 109 & 42 & 0 \\
\hline & Late & 30 (Range 3-88) & 30 & 199 & 19 & 19 & 139 & 22 & 0 \\
\hline \multirow{2}{*}{ Khatod et al. } & Early & \multirow{2}{*}{34 (Range 6-90) } & NA & 73 & 12 & 37 & 12 & 5 & 7 \\
\hline & Late & & NA & 30 & 7 & 9 & 11 & 3 & 0 \\
\hline
\end{tabular}




\section{Cureus}

\begin{tabular}{|c|c|c|c|c|c|c|c|c|c|}
\hline \multirow{2}{*}{ Spencer et al. (35\%) } & Early & NA & NA & 27 & 5 & 4 & 8 & 9 & NA \\
\hline & Late & NA & NA & 14 & 5 & 1 & 6 & 2 & 0 \\
\hline \multirow{2}{*}{ Sungaran et al. } & Early & NA & NA & 65 & 7 & 10 & 48 & & \\
\hline & Late & NA & NA & 96 & 21 & 25 & 50 & & \\
\hline \multirow{2}{*}{ Kamat et al. } & Early & NA & NA & 62 & 19 & 21 & 12 & & \\
\hline & Late & NA & NA & 41 & 30 & 11 & 10 & & \\
\hline \multirow{2}{*}{ Enninghorst et al. } & Early & \multirow{2}{*}{$41+7$} & \multirow{2}{*}{66} & 46 & NA & NA & NA & NA & NA \\
\hline & Late & & & 43 & NA & NA & NA & NA & NA \\
\hline \multirow{2}{*}{ Singh et al. } & Early & \multirow{2}{*}{32.4 (Range 7-89) } & \multirow[b]{2}{*}{54} & 38 & 0 & 0 & 38 & & \\
\hline & Late & & & 29 & 0 & 0 & 29 & & \\
\hline \multirow{2}{*}{ Reuss and Cole } & Early & NA & 23 & 31 & 5 & 5 & 2 & 15 & 4 \\
\hline & Late & NA & 40 & 50 & 9 & 14 & 7 & 19 & 1 \\
\hline \multirow{2}{*}{ Harley et al. } & Early & NA & NA & 41 & \multirow{2}{*}{19} & \multirow{2}{*}{53} & \multirow{2}{*}{37} & & \\
\hline & Late & NA & NA & 48 & & & & & \\
\hline \multirow{2}{*}{ Fernandes et al. } & Early & NA & NA & NA & NA & NA & NA & NA & NA \\
\hline & Late & NA & NA & NA & NA & NA & NA & NA & NA \\
\hline \multirow{2}{*}{ Hendrickson et al. } & Early & 47 (Range 18-98) & NA & 44 & 0 & 0 & 0 & 44 & 0 \\
\hline & Late & 53 (Range 17-93) & NA & 72 & 0 & 0 & 0 & 72 & 0 \\
\hline \multirow{4}{*}{ Li et al. } & $\leq 6$ Hours & \multirow{4}{*}{$48.5+3.6$} & \multirow{4}{*}{117} & 65 & \multirow{4}{*}{62} & \multirow{4}{*}{98} & \multirow{4}{*}{26} & \multirow{4}{*}{25} & \multirow{4}{*}{4} \\
\hline & $6 \mathrm{~h}<$ LFITFD $\leqq 12 \mathrm{~h}$ & & & 95 & & & & & \\
\hline & $12 \mathrm{~h}<\mathrm{LFITFD} \leqq 24 \mathrm{~h}$ & & & 36 & & & & & \\
\hline & LFITFD > $24 \mathrm{~h}$ & & & 19 & & & & & \\
\hline \multirow{2}{*}{ Pollak et al. } & Early & \multirow{2}{*}{ (Range 16-69) } & NA & 93 & NA & NA & NA & NA & NA \\
\hline & Late & & NA & 214 & NA & NA & NA & NA & NA \\
\hline \multirow{4}{*}{ Srour et al. $(48.3 \%)$} & $<6$ & $37.0(17.2)$ & 46 & 64 & 9 & 22 & 18 & 9 & 6 \\
\hline & 7 to 12 Hours & $33.8(15.8)$ & 54 & 70 & 13 & 24 & 22 & 8 & 3 \\
\hline & 13 to 18 Hours & $32.4(17.8)$ & 81 & 98 & 33 & 28 & 23 & 10 & 4 \\
\hline & 19 to 24 Hours & $33.4(14.2)$ & 68 & 83 & 15 & 20 & 32 & 14 & 2 \\
\hline \multirow{2}{*}{ Al-Arabi et al. $(<50 \%)$} & Early & \multirow{2}{*}{41} & NA & 154 & & & & & \\
\hline & I ate & & NA & 04 & 11 & 54 & 65 & 52 & 0 \\
\hline
\end{tabular}

TABLE 2: Baseline characteristics of the included studies

LFITFD: Length from injury to first debridement

With regard to the risk of bias, all prospective studies reported adequate selection of the cases; the comparability was adequate in most of the prospective studies as well. The drop-out rate was adequate in all included, prospective, studies; however, no clear descriptions were provided regarding the method of assessment of infection. The overall quality of the prospective studies was moderate-to-high. On the other hand, the selection, comparability, and exposure domains were deemed adequate in most of the included retrospective studies (Appendix 1).

The pooled effect estimate showed no statistically significant difference between early and late debridement regarding the overall infection rate (RD 0.02, 95\% CI [0 - 0.04], $\mathrm{p}=0.94$; Figure 2); there was no significant 


\section{Cureus}

heterogeneity in the pooled estimate $(\mathrm{I} 2=5 \%$ ). The subgroup analysis showed that the non-significant difference was consistent regardless of the definition of early and late timing to debridement (Figure 2).

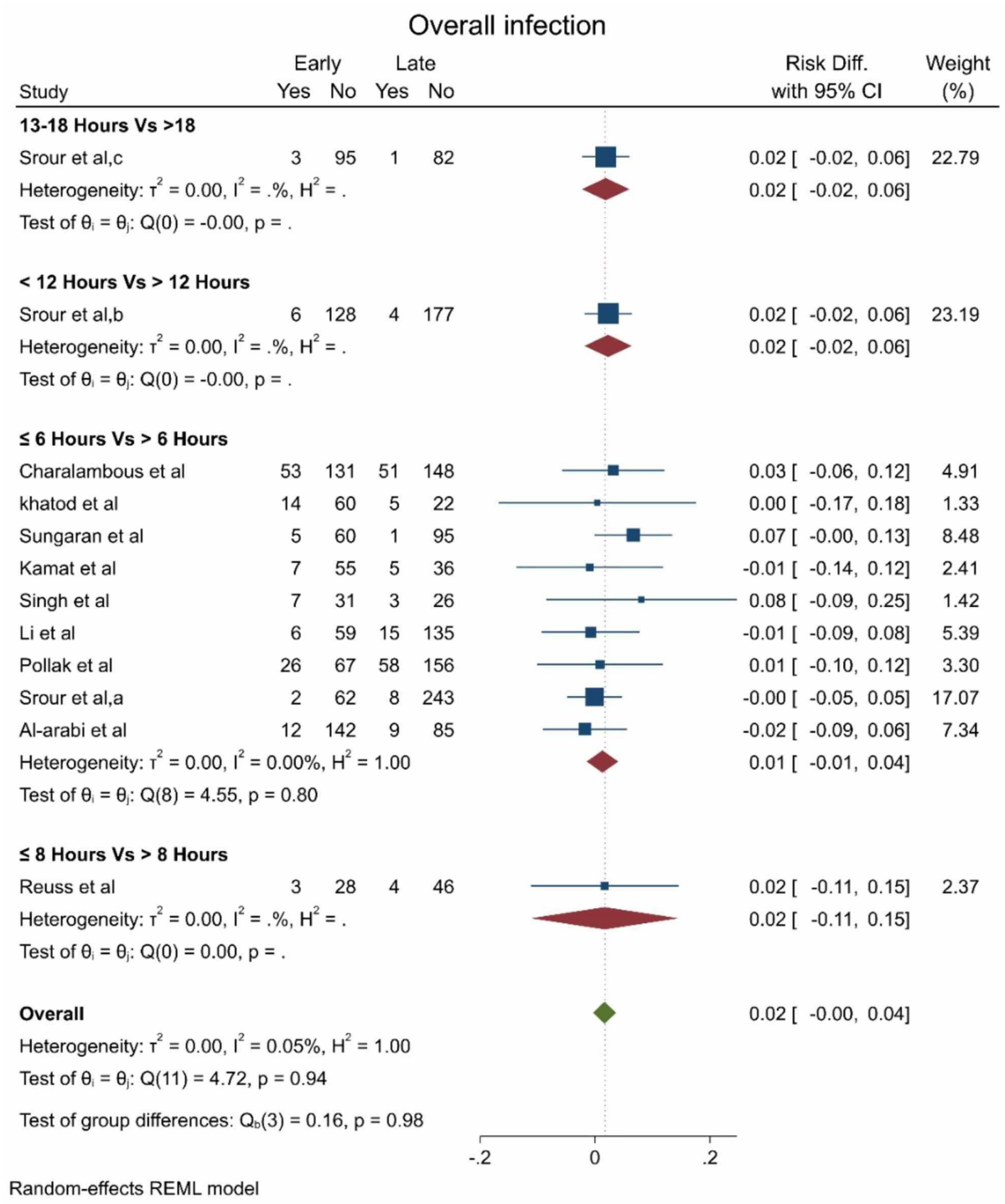

\section{FIGURE 2: The overall infection rate}

Likewise, the pooled effect estimate showed no statistically significant difference between early and late debridement regarding the deep infection rate ( $R D 0.01,95 \%$ CI [-0.01 - 0.03], p = 0.92; Figure 3); there was no significant heterogeneity in the pooled estimate $(\mathrm{I} 2=0 \%)$. 


\section{Cureus}

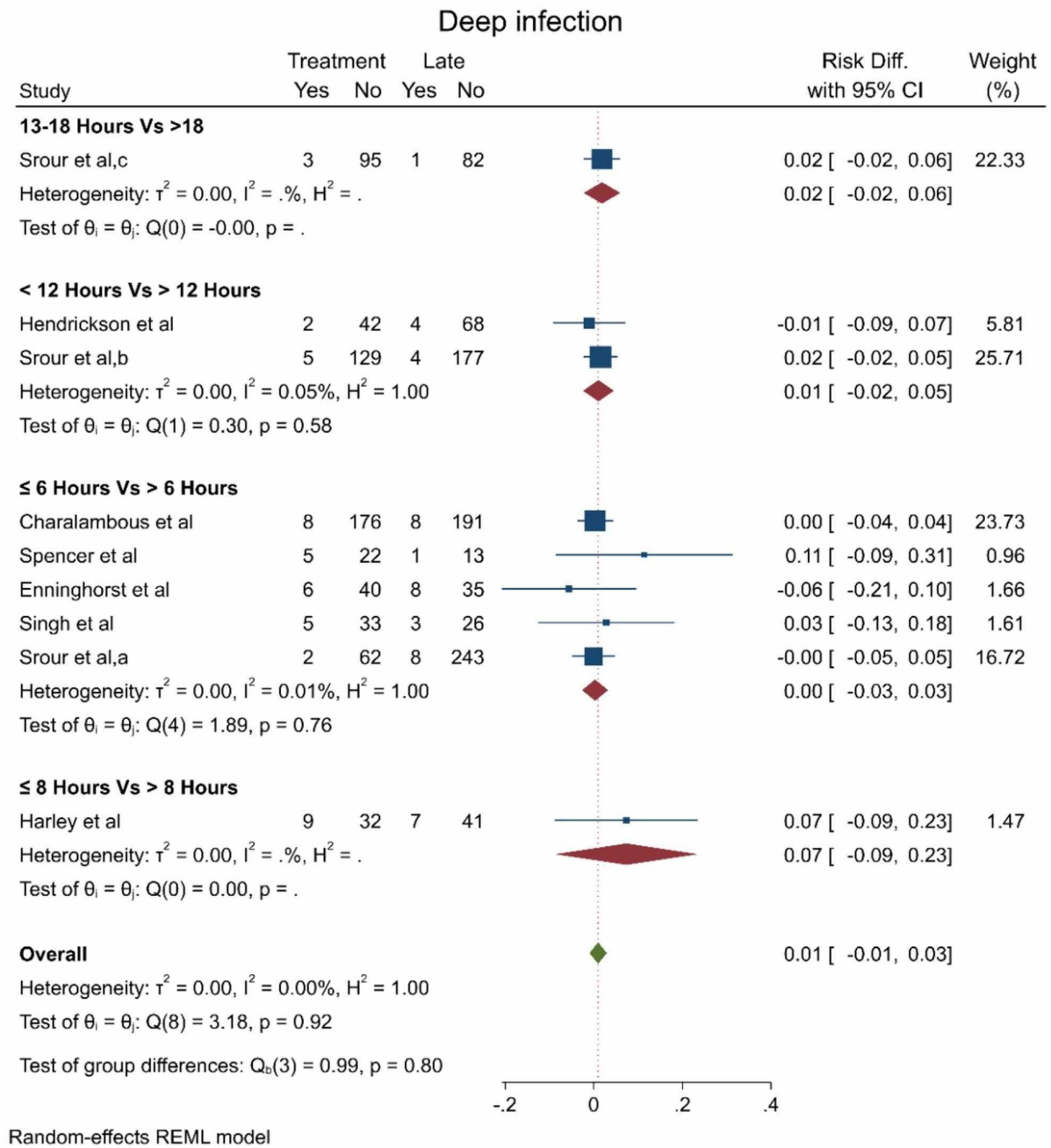

FIGURE 3: The deep infection rate

The pooled effect estimate showed no statistically significant difference between early and late debridement regarding the non-union rate as well (Figure 4). 


\section{Cureus}

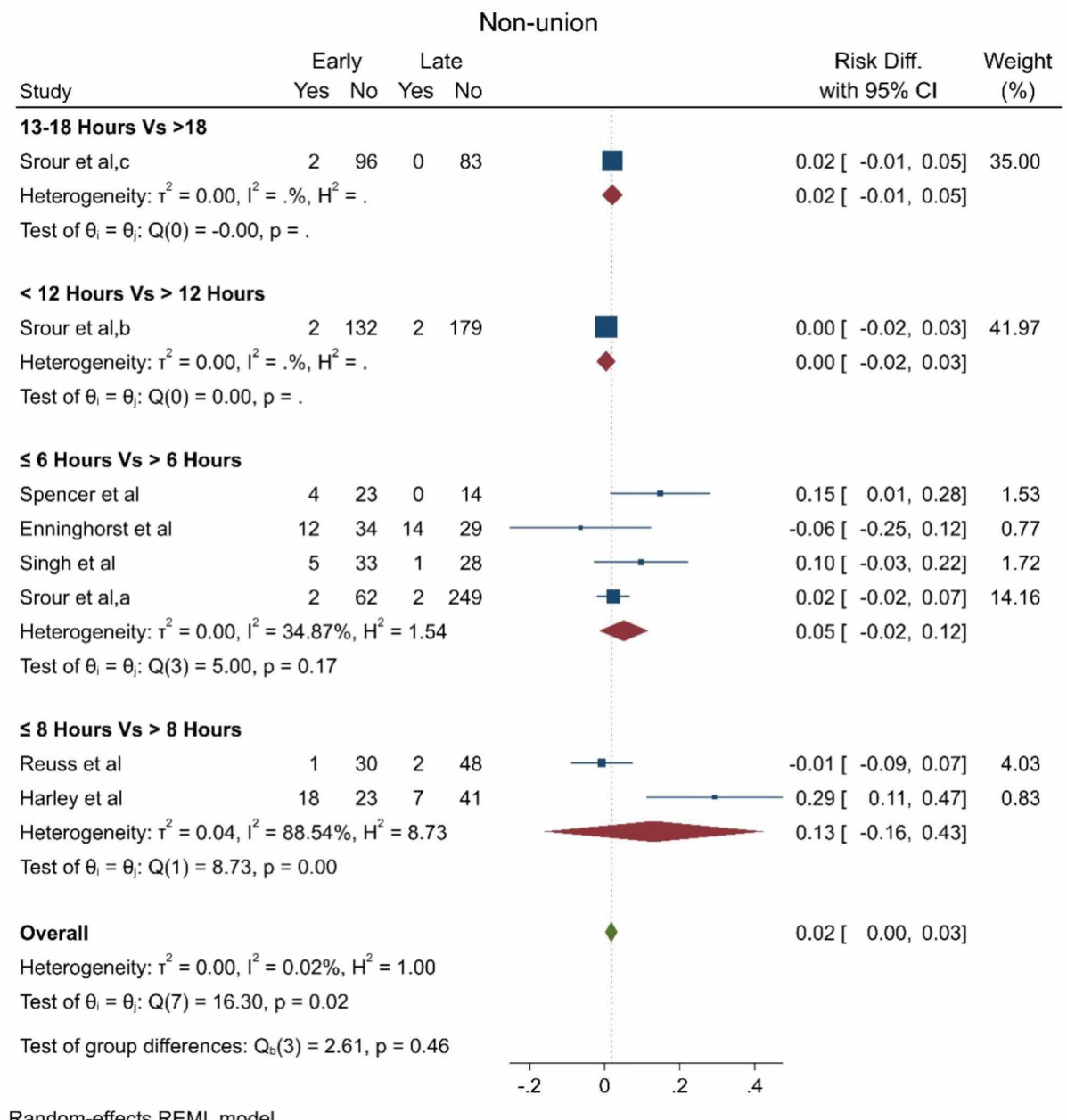

FIGURE 4: The nonunion rate

The funnel plots showed little evidence of asymmetry by visual inspection (Figure 5).

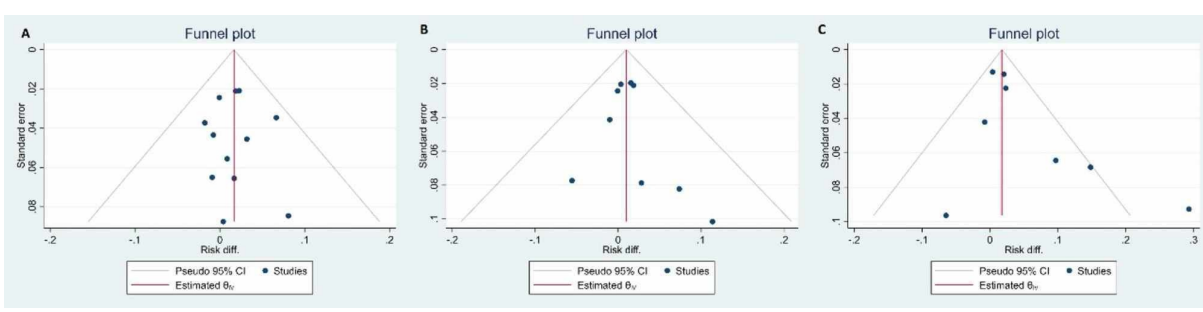

FIGURE 5: The funnel plots

\section{Discussion}

Previously, it was commonly believed that open tibial fractures should undergo debridement and antibiotic administration with a maximum of six hours from injury; however, this concept has been challenged recently with a growing body of evidence. In this review, we aimed to provide updated evidence about the relation between the timing to debridement and the rate of infection. We found that the early debridement did not lead to a significant reduction in the risk of infection compared to late debridement. Besides, the pooled estimates showed no significant difference between early and late debridement regarding the deep infection and nonunion rates.

Infection is a major concern to orthopedic surgeons while treating open, long bone, fractures; it is a prevalent complication during the management of open fractures, especially with extensive tissue damage and contamination [20]. In the case of extensive or deep infection, the fracture can be complicated by the dysfunction of the limb, several organ failures, and mortality [3]. Thus, many strategies, mainly based on 
emergency measures, have been proposed to reduce the risk of infection in patients with long bone fractures. Early debridement within six hours from a fracture is the most widely accepted method for infection control in open fractures [21]. However, deriding the injury within six hours can be challenging in a real-life setting due to severe conditions [9]. Thus, previous reports have tried to investigate whether late debridement would significantly increase the risk of infection in patients with open fractures [24]. In this updated review, we demonstrated that late debridement did not lead to a significant increase in the risk of overall and deep infection rates among patients with open tibial fractures. This finding was consistent with a 2016 meta-analysis study, which showed a significant increase in the risk of infection in patients who underwent delayed surgical debridement (> 6 hours) [1]. In Schenker et al. systematic review, the risk of infection did not increase with delayed debridement [2]. The same findings were observed in the pediatric population [26]. The limited role of timing of debridement on the rate of infection can be explained by advances in antibiotics, fracture stabilization, and wound management strategies. Notably, our subgroup analysis demonstrated no significant increase in the risk of infection even when the debridement was delayed for 24 hours. In Srour et al. study, the patients, who underwent surgical debridement within 18-24 hours from injury, had similar infection rates to patients with earlier debridement [24]. The same results were reported by Li et al. [6].

While the present systematic review has the advantages of a comprehensive search of databases, homogeneity of pooled estimates, lack of substantial publication bias, and moderate-to-high quality of the included studies, we acknowledge the presence of some limitations. The findings of the present systematic review are mainly based on retrospective studies with their well-established limitations regarding misclassification and information biases. In addition, the data were limited to perform a meta-regression analysis in order to examine potential influencers of infection rate within the included studies. The inconsistencies in defining the infection and non-union, timing to surgery, and severity of fractures of included patients are other limitations.

\section{Conclusions}

In conclusion, the current evidence demonstrates no impact of timing to surgical debridement on the infection rate following open tibial fractures in adult population. Our results demonstrated that the risks of infection, deep infection, and nonunion were similar between patients underwent delayed versus early debridement. Notably, these findings were consistent even when the delay extent to more than 12 hours after the injury. While emergent debridement within 24 hours is essential, the 6-hour rule should not be universally applied and the treating surgeons should consider several factors before deciding to urgently debride the wound within six hours from injury. Further, high-quality, evidence is still needed.

\section{Appendices}




\section{Cureus}

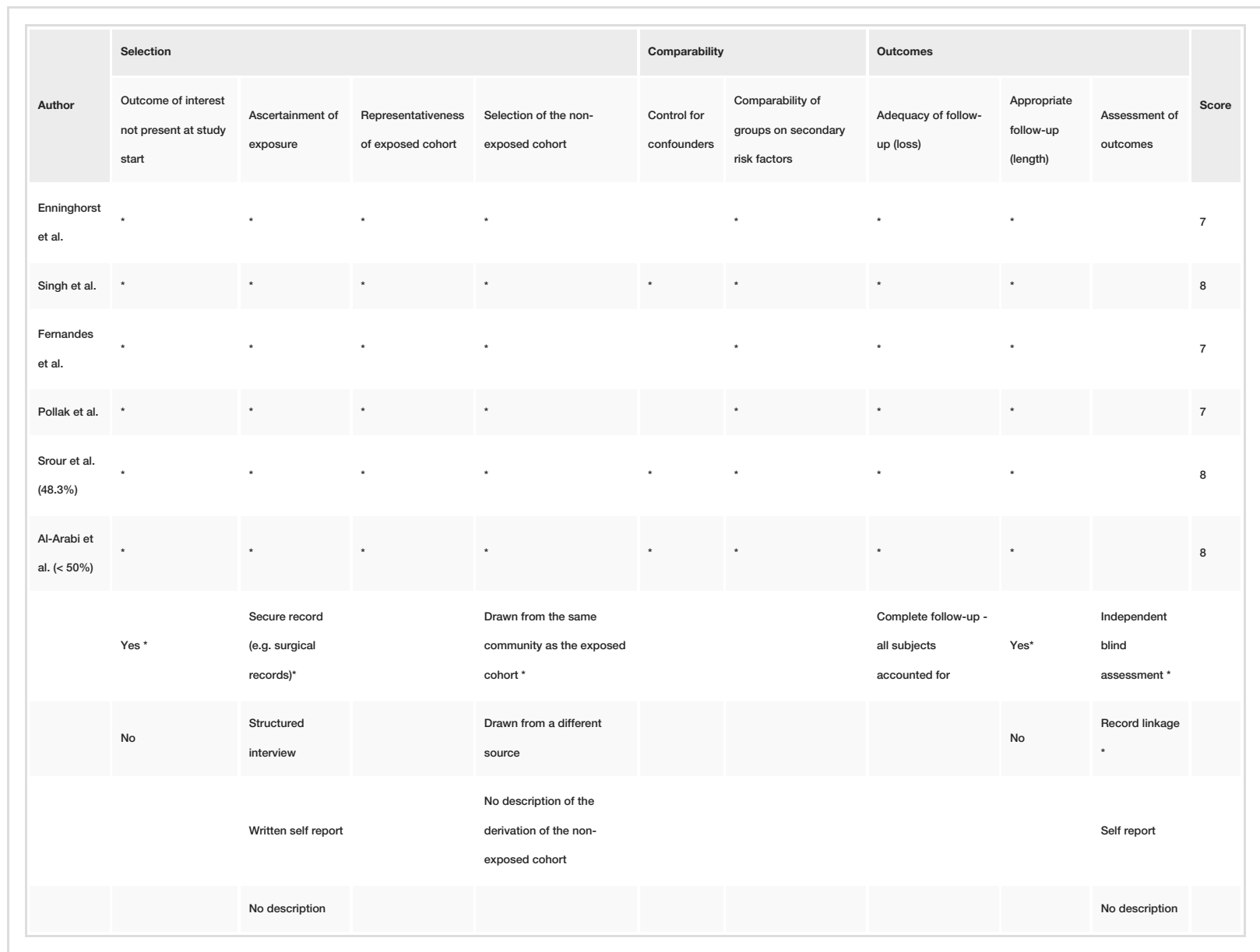

TABLE 3: Quality assessment of prospective studies 


\section{Cureus}

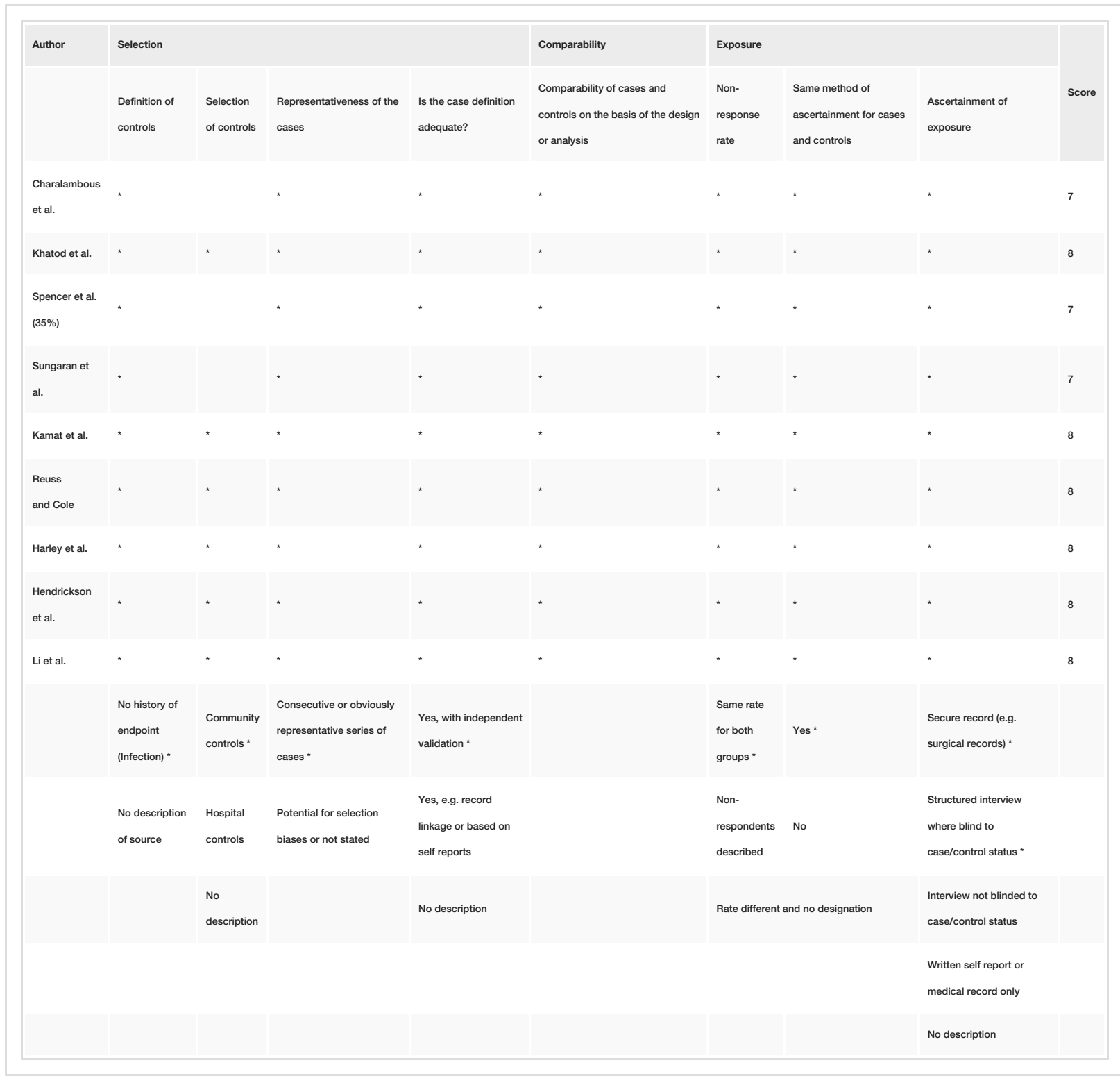

TABLE 4: Quality assessment of retrospective studies

\section{Additional Information \\ Disclosures}

Human subjects: All authors have confirmed that this study did not involve human participants or tissue. Animal subjects: All authors have confirmed that this study did not involve animal subjects or tissue. Conflicts of interest: In compliance with the ICMJE uniform disclosure form, all authors declare the following: Payment/services info: All authors have declared that no financial support was received from any organization for the submitted work. Financial relationships: All authors have declared that they have no financial relationships at present or within the previous three years with any organizations that might have an interest in the submitted work. Other relationships: All authors have declared that there are no other relationships or activities that could appear to have influenced the submitted work.

\section{References}

1. Prodromidis AD, Charalambous CP: The 6-hour rule for surgical debridement of open tibial fractures: a systematic review and meta-analysis of infection and nonunion rates. J Orthop Trauma. 2016, 30:397-402. 10.1097/BOT.0000000000000573

2. Schenker ML, Yannascoli S, Baldwin KD, Ahn J, Mehta S: Does timing to operative debridement affect infectious complications in open long-bone fractures? A systematic review. J Bone Jt Surg. 2012, 94:10571064. 10.2106/JBJS.K.00582

3. Enninghorst N, McDougall D, Hunt JJ, Balogh ZJ: Open tibia fractures: timely debridement leaves injury 
severity as the only determinant of poor outcome. J Trauma Inj Infect Crit Care. 2011, 70:352-357. 10.1097/TA.0b013e31820b4285

4. Spencer J, Smith A, Woods D: The effect of time delay on infection in open long-bone fractures: a 5-year prospective audit from a district general hospital. Ann R Coll Surg Engl. 2004, 86:108-112. 10.1308/003588404322827491

5. Al-Arabi YB, Nader M, Hamidian-Jahromi AR, Woods DA: The effect of the timing of antibiotics and surgical treatment on infection rates in open long-bone fractures: a 9-year prospective study from a district general hospital. Injury. 2007, 38:900-905. 10.1016/j.injury.2007.02.043

6. Li J, Wang Q, Lu Y, Feng Q, He X, Li Z, Zhang K: Relationship between time to surgical debridement and the incidence of infection in patients with open tibial fractures. Orthop Surg. 2020, 12:524-532.

7. Marecek GS, Nicholson LT, Auran RT, Lee J: Use of a defined surgical approach for the debridement of open tibia fractures. J Orthop Trauma. 2018, 32:1-4. 10.1097/BOT.0000000000000998

8. Friedrich PL: Die aseptische Versorgung frischer Wunden, unter Mittheilung von Thier-Versuchen über die Auskeimungszeit von Infectionserregern in frischen Wunden. Arch fur Klinsche Chirugie. 1898, 288-310.

9. Namdari S, Baldwin KD, Matuszewski P, Esterhai JL, Mehta S: Delay in surgical débridement of open tibia fractures: an analysis of national practice trends. J Orthop Trauma. 2011, 25:140-144. 10.1097/BOT.0b013e3181e3dff1

10. Pollak AN, Jones AL, Castillo RC, Bosse MJ, MacKenzie EJ: The relationship between time to surgical débridement and incidence of infection after open high-energy lower extremity trauma. J Bone Jt Surg - Ser A. 2010, 92:7-15. 10.2106/JBJS.H.00984

11. Sungaran J, Harris I, Mourad M: The effect of time to theatre on infection rate for open tibia fractures . ANZ J Surg. 2007, 77:886-888. 10.1111/j.1445-2197.2007.04266.x

12. Harley BJ, Beaupre LA, Jones CA, Dulai SK, Weber DW: The effect of time to definitive treatment on the rate of nonunion and infection in open fractures. J Orthop Trauma. 2002, 16:484-490. 10.1097/00005131200208000-00006

13. Lack WD, Karunakar MA, Angerame MR, Seymour RB, Sims S, Kellam JF, Bosse MJ: Type III open tibia fractures: immediate antibiotic prophylaxis minimizes infection. J Orthop Trauma. 2015, 29:1-6. 10.1097/BOT.0000000000000262

14. Tripuraneni K, Ganga S, Quinn R, Gehlert R: The effect of time delay to surgical debridement of open tibia shaft fractures on infection rate. Orthopedics. 2008, 31:10.3928/01477447-20081201-27

15. Singh J, Rambani R, Hashim Z, Raman R, Sharma HK: The relationship between time to surgical debridement and incidence of infection in grade III open fractures. Strategies Trauma Limb Reconstr. 2012, 7:33-37. 10.1007/s11751-012-0130-y

16. Higgins J, Green S: Cochrane Handbook for Systematic Reviews of Interventions . John Wiley \& Sons, 2019. 10.1002/9781119536604

17. Moher D, Liberati A, Tetzlaff J, Altman DG, PRISMA Group: Preferred reporting items for systematic reviews and meta-analyses: the PRISMA statement. PLoS Med. 2009, 6:e1000097. 10.1371/journal.pmed.1000097

18. Wells G, Shea B, O’Connell D, Peterson J, Welch V, Losos M, Tugwell P: The Newcastle-Ottawa Scale (NOS) for assessing the quality of non-randomized studies in meta-analyses. J Hellenic Studies. 2013, $10.2307 / 632432$

19. Charalambous CP, Siddique I, Zenios M, Roberts S, Samarji R, Paul A, Hirst P: Early versus delayed surgical treatment of open tibial fractures: effect on the rates of infection and need of secondary surgical procedures to promote bone union. Injury. 2005, 36:656-661. 10.1016/j.injury.2004.10.007

20. Khatod M, Botte MJ, Hoyt DB, Meyer RS, Smith JM, Akeson WH: Outcomes in open tibia fractures: relationship between delay in treatment and infection. J Trauma. 2003, 55:949-954. 10.1097/01.TA.0000092685.80435.63

21. Kamat AS: Infection rates in open fractures of the tibia: is the 6-hour rule fact or fiction? . Adv Orthop. 2011, 2011:1-4. 10.4061/2011/943495

22. Reuss BL, Cole JD: Effect of delayed treatment on open tibial shaft fractures . Am J Orthop. 2007, 36:216-220.

23. Hendrickson SA, Wall RA, Manley O, et al.: Time to initial debridement and wound excision (TIDE) in severe open tibial fractures and related clinical outcome: a multi-centre study. Injury. 2018, 49:1922-1926.

24. Srour M, Inaba K, Okoye O, et al.: Prospective evaluation of treatment of open fractures: effect of time to irrigation and debridement. JAMA Surg. 2015, 150:332-336. 10.1001/jamasurg.2014.2022

25. de Castro Fernandes M, Peres LR, de Queiroz Neto AC, Lima Neto JQ, Turíbio FM, Matsumoto MH: Open fractures and the incidence of infection in the surgical debridement 6 hours after trauma. Acta Ortop Bras. 2015, 23:38-42. 10.1590/1413-78522015230100932

26. Ibrahim T, Riaz M, Hegazy A, Erwin PJ, Tleyjeh IM: Delayed surgical debridement in pediatric open fractures: a systematic review and meta-analysis. J Child Orthop. 2014, 8:135-141. 10.1007/s11832-0140567-2 